\title{
Economia de comunhão e outras economias: um discernimento antropológico-teológico
}

\author{
Orientador: Joel Portella Amado
}

Mestrando: Roberto Cintra Martins

Área de Concentração: Teologia Sistemático-Pastoral

Linha de Pesquisa: Religião e Modernidade

Com este trabalho, pretende-se estudar e confrontar os pressupostos antropológicos e teológicos de duas diferentes concepções de economia: os da economia atualmente preponderante, calcada no individualismo e no utilitarismo e os de um novo modelo econômico recente e bem menos conhecido, de raízes cristãs, a Economia de Comunhão (EdC). Paradoxalmente, a EdC é ainda pouco conhecida em meio católico e assim esta dissertação toma também para si a tarefa de contribuir para um seu melhor entendimento.

Estamos muito distantes de conceber a EdC como "um novo modo de agir econômico", "uma nova forma de gestão empresarial" ou de "economia solidária", buscando mostrar, isto sim, que a EdC é sobretudo uma opção antropológica e espiritual que transborda estes territórios, desembocando na prática empresarial e deitando suas raízes em uma específica concepção do ser humano.

O trabalho inclui uma descrição da própria EdC, suas origens, características e implicações teológicas, sua história e pré-história, sua identidade e missão, bem como as visões críticas a seu respeito.

Como parte indispensável, a dimensão propriamente antropológico-teológica da EdC e a concepção típica da antropologia teológica cristã em geral serão estudadas e comparadas.

Palavras-chave: Economia; comunhão; fundamentos antropológico-teológicos. 